\title{
Health impact of disinfection by-products in swimming pools
}

\author{
Cristina M. Villanueva and Laia Font-Ribera \\ Centre for Research in Environmental Epidemiology (CREAL), Barcelona, Spain
}

\begin{abstract}
This article is focused on the epidemiological evidence on the health impacts related to disinfection by-products (DBPs) in swimming pools, which is a chemical hazard generated as an undesired consequence to reduce the microbial pathogens. Specific DBPs are carcinogenic, fetotoxic and/or irritant to the airways according to experimental studies. Epidemiological evidence shows that swimming in pools during pregnancy is not associated with an increased risk of reproductive outcomes. An epidemiological study suggested an increased risk of bladder cancer with swimming pool attendance, although evidence is inconclusive. A higher prevalence of respiratory symptoms including asthma is found among swimming pool workers and elite swimmers, although the causality of this association is unclear. The body of evidence in children indicates that asthma is not increased by swimming pool attendance. Overall, the available knowledge suggests that the health benefits of swimming outweigh the potential health risks of chemical contamination. However, the positive effects of swimming should be enhanced by minimising potential risks.

Key words: swimming pools, disinfection by-products, epidemiology.
\end{abstract}

Riassunto (Impatto sulla salute dei sottoprodotti di disinfezione nelle piscine). Questo articolo è incentrato sulle evidenze epidemiologiche riguardanti gli effetti sulla salute associati ai sottoprodotti della disinfezione (DBPs) nelle piscine, la cui presenza è una conseguenza indesiderata dei trattamenti di disinfezione per il controllo dei microrganismi patogeni. Sulla base di studi sperimentali, specifici DBPs sono risultati cancerogeni, fetotossici e/o irritanti delle vie respiratorie. Le evidenze epidemiologiche mostrano che nuotare nelle piscine durante la gravidanza non è associato ad un incremento di rischio di danni riproduttivi. Uno studio epidemiologico ha suggerito un incremento di rischio di cancro alla vescica associato alla frequentazione delle piscine, sebbene le evidenze non permettano di trarre conclusioni certe. Una più alta prevalenza di sintomi respiratori inclusa l'asma è stata trovata tra il personale che opera all'interno delle piscine e i nuotatori ad alta frequentazione, sebbene la causalità di questa associazione non sia chiara. Il peso delle evidenze nei bambini indica che l'asma non aumenta con la frequentazione delle piscine. Complessivamente, le conoscenze attuali suggeriscono che gli effetti benefici del nuotare superano i rischi potenziali per la salute dovuti alla contaminazione chimica. Tuttavia, questi effetti positivi dovrebbero essere aumentati minimizzando i rischi potenziali.

Parole chiave: piscine, sottoprodotti di disinfezione, epidemiologia.

\section{INTRODUCTION}

Swimming is a highly practiced sport. There is no question that many positive aspects are associated to swimming in pools, including those from physical activity, back pain relief, and wellbeing from leisure and recreation. In contrast, the World Health Organization identifies 3 hazards in swimming pools: injury/drowning, microbial hazards and chemical hazards [1]. Consequently, eventual positive health effects gained by swimming can be increased by reducing the potential adverse health risks [2]. We will focus this review on the negative impacts related to disinfection by-products (DBPs), which is a chemical hazard generated as an undesired consequence to reduce the microbial hazards.

\section{OCCURRENCE OF DISINFECTION BY-PRODUCTS IN SWIMMING POOLS}

Disinfection is necessary in swimming pools to maintain hygienic conditions and avoid water-borne infections. Chlorine is the most widely used disinfectant, that in the presence of organic matter from bathers (urine, sweat, hair, cells, cosmetics, etc.) re- 
acts to generate by-products [2,3]. Many by-products identified in swimming pools also occur in drinking water $[4,5]$. Disinfection by-products occurring at higher concentrations both in drinking water and swimming pools are trihalomethanes (THMs) and haloacetic acids (HAAs). Haloacetoaldehydes, especially trichloroacetaldehyde (chloral hydrate, $\mathrm{CH}$ ), have also been identified in swimming pools [6]. The presence of nitrogen-containing organic matter from bathers leads to the formation of nitrogenated by-products such as chloramines (mochloramine, dichloramine, trichloramine), haloacetonitriles (HANs) [7] and carcinogenic nitrosamines [8, 9]. Trichloramine is a volatile, irritant compound of penetrating odor, whose main precursors are urea, ammonium ions and $\alpha$-amino acids [10]. A survey conducted in 86 swimming pools in Seoul, Korea, showed that HAAs occurred at highest concentrations in all swimming pools, regardless of disinfection method, followed by THMs, $\mathrm{CH}$, and HANs [11]. Haloacetic acids also occur in air of swimming pools, in the form or aerosols [12]. Although more than 600 DBPs have been identified, this figure represents less than $50 \%$ of total organic halides, and new by-products are to be identified [5].

The formation of DBPs in swimming pools depends on several factors, including the amount of precursors in the water. Levels of THMs in water are correlated with the number of people in the pool, water temperature, and the amount of total organic carbon [13]. Air-water THM concentrations are highly correlated $[14,15]$, and it has been shown that both THM and trichloramine levels in air increases with the number of swimmers $[14,16$, 17] and is also influenced by the volume of total air in the hall [16]. Higher levels have been observed in winter compared to summer, depicting that low air exchange rate in winter lead to accumulation of pollutants [16]. Outdoor compared to indoor pools tend to show higher THM levels in water [18]. Air trichloramine levels are associated with bather loading [19], air temperature and $\mathrm{pH}$ [16].

Many by-products of chlorination are genotoxic [4]. However, the mutagenic or genotoxic potency of swimming pool water has been evaluated in very few studies. Mutagenicity was assessed by Richardson et al. [5] in samples collected in Barcelona, Spain. The authors concluded that swimming pool waters were as mutagenic as typical drinking waters [5]. Genotoxicity of water concentrates from recreational pools after various disinfection methods was evaluated by Liviac et al. [20], showing that all disinfected recreational pool water samples induced more genomic DNA damage than the source tap water. They also found that the type of disinfectant and illumination conditions altered the genotoxicity of the water. A previous study evaluated genotoxicity of swimming pool water, observing strongest potencies in the low-molecular weight fraction [21]. The implications are that removal of DBPs with higher genotoxic potential requires membrane treatment with low-molecular weight cut offs, which is an advanced treatment not generally used in swimming pools. Later, it has been shown that pool water quality could be improved with nano- and ultrafiltration, compared to the conventional treatment [22].

Alternative disinfectants used in swimming pools include advanced processes like ozonation, coppersilver ionization, UV radiation, among others. Some of them (e.g. ozonation) are used in combination with chlorination. The formation of chlorination by-products are reduced by the use of these alternative disinfection methods, as illustrated by a study conducted in Seoul, Korea, where THMs, HAAs, HANs and $\mathrm{CH}$ levels were lower in chlorine/ozone swimming pools compared to only chlorinated pools [11]. However, these alternative disinfection processes still involve the formation of by-products of concern $[23,24]$. For example, bromate is generated by ozonation if bromine is present in the water [25]. Bromine-based disinfectants are also used in some swimming pools and spa, where brominated DBPs are produced in highest concentrations [15].

Disinfection by-products are regulated in drinking water in most western countries, where trihalomethanes and bromate are routinely measured [26], as well as haloacetic acids in the US [27]. The World Health Organization suggests that trichloramine should be monitored in swimming pools and the recommended guideline is set at $0.5 \mathrm{mg} / \mathrm{m}^{3}$ [1]. However, this recommendation is not included in the local regulations for swimming pools, and DBPs are not controlled in swimming pools on a regular basis.

\section{HUMAN EXPOSURE}

Exposure to DBPs in swimming pools occurs mainly through inhalation of volatile DBPs or aerosol containing DBPs and through dermal absorption of skin-permeable DBPs. Volatile DBPs include THMs and trichloramine, among many others [7, 28]. Swimming pool attendance represents a relevant contribution in the total burden of THM exposure, especially when subjects drink bottled water [29].

Human exposure to THMs in swimming pools has been evaluated in several studies that measured THMs in blood, exhaled air and urine. While the four THMs (chloroform, bromodichloromethane, dibromochloromethane and bromoform) can be measured in exhaled air, only chloroform is usually detected in blood $[30,31]$. Chloroform and bromodichloromethane are the only THMs detected in urine [32]. In consequence, it has been suggested that alveolar air would be the most sensitive exposure biomarker [33], particularly at low environmental levels [34]. Level of physical activity is correlated with internal dose $[15,17,31,35,36]$. The relative importance of inhalation vs. dermal absorption has been evaluated for chloroform. Lévesque et al. [37] dissociated the dermal from the inhalation exposure routes in 11 male swimmers and measured alveolar chloroform levels, concluding that approximately 
$24 \%$ of body burden resulted from dermal absorption. Erdinger et al. [38] found that blood levels were highly correlated with air levels and poorly correlated with water concentrations, suggesting that that inhalation would be more important than dermal absorption and estimated that one third of the total burden is taken up over the skin. On the contrary, Lindstrom et at. [39] estimated that dermal exposure accounted for $80 \%$ of the blood concentration, based on alveolar air measurements in 2 elite swimmers.

Although HAAs are non-volatile and have little skin permeability, swimmers may be exposed through inhalation of aerosol [12]. Internal dose of HAAs in 49 swimmers and pool workers has been measured in urine by Cardador et al. [40]. Dichloroacetic (DCAA) and trichloroacetic (TCAA) acids were detected in urine among workers after two hours of exposure. After $1 \mathrm{~h}$ swimming, TCAA, DCAA and monochloracetic acid (MCAA) were detected in swimmers at concentrations much higher than those measured in workers. Similar results were obtained from swimmers in an outdoor pool due to accidental ingestion. The authors estimate that ingestion is the major route of exposure (94\%), followed by inhalation $(5 \%)$ and dermal contribution (1\%). Personal exposure assessment using biomarkers has not been conducted for other DBPs.

\section{RESPIRATORY HEALTH}

First evidence that swimming pool environment can be toxic for respiratory health come from case reports of acute intoxication in swimming pools due to accidental chlorine exposures [41-44]. Symptoms described by these cases vary according to the level of exposure and include eye and airway irritation, cough, wheezing and shortness of breath, and in worst cases, respiratory impairment requiring mechanical ventilation $[45,46]$. Epidemiological studies have mainly been focused on three specific populations: pool workers, professional swimmers and children. Workers and elite swimmers are highly exposed populations, and children are particularly vulnerable to environmental insults.

\section{Occupational exposure}

Swimming pools are the occupational environment of lifeguards, swimming trainers and professional swimmers. This chronic occupational exposure has been studied in relation to respiratory symptoms. Massin et al. described in France that trichloramine levels in swimming pools' air were associated with the prevalence of eye and nasal irritant symptoms among 334 lifeguards working in the pools, but not with the prevalence of chronic respiratory symptoms such as bronchial hyperreactivity [47]. Jacobs et al. also found that among 624 swimming pool workers in The Netherlands, lifeguards and swimming trainers had higher prevalence of nasal symptoms but not bronchial hyperreactivity than other work- ers not directly exposed to the swimming pool environment [48]. In Italy, a study among 115 swimming pool workers found that those exposed to higher DBP levels (measured with THM in exhaled breath) had higher prevalence of asthma, although only 10 asthmatics were included [49]. In a water park in US, lifeguards had higher prevalence of cough, shortness of breath and wheezing than workers not directly exposed to the pool environment [50]. Due to the cross-sectional design of these studies, a healthy worker effect could have occurred in the studies; i.e., self-selection by workers, with sensitive subjects quitting or avoiding this job. On the other hand, Thickett, et al. described 3 cases of occupational asthma due to trichloramine sensitization in swimming pool lifeguards [51].

\section{Elite swimmers}

Different studies have described higher prevalence of asthma or respiratory symptoms among swimmers than among other competitive athletes $[46,52$, 53]. In 2008, Goodman and Hays published a meta-analysis including 6 studies and found a higher prevalence of asthma among swimmers compared to other elite athletes $(\mathrm{OR}=2.57 ; 95 \% \mathrm{CI}=1.87$ 3.54) [54]. The authors stated that asthmatics are more frequently found among swimmers but that the cause of this association is not clear. The chronic exposure to the irritant environment could lead to an increased airway inflammation and more asthma symptoms among swimmers [55]. On the other hand, asthmatics may be more prone to choose swimming compared to other sports and therefore more asthmatics are found among swimmers. Swimming is one of the less asthmagenic and more safe sports to practice for asthmatic patients $[56,57]$ and it is the recommended sport for them [58]. In 72 young competitive swimmers, Levesque et al. found that those exposed to higher levels of trichloramine in air had higher prevalence of upper respiratory symptoms [52]. Recent studies have described also higher prevalence of asthma symptoms among competitive swimmers than among the general population [59, 60]. In summary, swimmers have higher prevalence of asthma compared to other athletes. However, the direction of the association is not clear and both chemical exposure and the preference of swimming among asthmatics may be responsible for the detected association [53-55].

\section{Children}

The possibility that the exposure to the swimming pool environment can affect respiratory health of recreational swimmers and especially among children has raised concern in recent years [55, 61-69]. If a causal association were detected, public health implications would be relevant [63]. On one hand, asthma is among the most common chronic diseases in children [70], with an increasing incidence, prevalence, morbidity, mortality and economic cost in recent decades [71]. On the other hand, swimming 
is one of the most practiced sports in western countries [72], where sedentarism and obesity are increasing, especially among children [73].

First studies were conducted in Belgium [7476], Germany [77, 78] and Italy [79]. The studies in Belgium found an increased risk of childhood asthma among atopic children related to both indoor and outdoor pool attendance, while the other studies did not. A metanalysis including these studies showed that the OR of having asthma was not increased with pool attendance among children [54]. However, several shortcomings were identified in the exposure assessment and the characterization of asthma [63]. Since then, two studies have been published in Belgium [80, 81]. Among 430 children at 6 years of age, an increased risk of bronchiolitis, but no wheezing or other respiratory symptoms, was found among those with higher pool attendance [81]. An increased risk of asthma was also found among adolescents with higher chlorinated pool attendance [80]. A small study in Ireland [82] found a significant association between asthma and the number of years attending pools among adolescents, but not with the frequency of attendance. A larger Spanish study found a null association among children 10 to 12 years old [83]. All epidemiological studies until that moment used a cross-sectional design with retrospective assessment of swimming pool attendance, which could have introduced recall bias, exposure misclassification and reverse causation $[55,62,63]$.

The first longitudinal prospective study used data from the ALSPAC child cohort in UK [84]. The study analysed 5738 children with data on swimming pool attendance collected at different time points during childhood and with data on respiratory health assessed with questionnaires and spirometry. The results indicated that swimming did not increase the risk of asthma, atopy or any respiratory and allergic symptom in children at 7 or 10 years of age [84]. On the contrary, swimming was associated with increased lung function and with a decreased prevalence of current asthma among children with previous respiratory conditions. This occurred regardless of the socioeconomic status of the family. This positive association between swimming and lung function could be explained by the benefits of physical activity on the respiratory health. In fact, there is growing evidence that physical activity during childhood $[77,85$, 86] or during adulthood [87] may decrease prevalence of allergic rhinitis [77], bronchial hyper reactivity [87] and asthma development $[85,86]$. If the results detected in the ALSPAC cohort are further confirmed, swimming would not only be a safe sport for people with asthma [56] but also may help control asthma symptoms [84]. Other recent studies also suggest that people with asthma may improve their asthma symptoms with swimming $[54,56,88,89]$.

The inconsistency of the results among studies may reflect true differences in the association between swimming and childhood asthma (due to different patterns of pool attendance or different level of irritants in the swimming pools) or may relate to methodological aspects. Only a few epidemiological studies have reported trichloramine levels $[75,80,83]$ and overall levels were below the $0.5 \mathrm{mg} / \mathrm{m}^{3}$ recommended by the World Health Organization [1]. Concerning the methodological differences, the studies with null associations [77, 78, 83, 84] are based on large and population-based samples, whereas the studies with positive results are based on smaller datasets [74-76; 80-82]. Epidemiological studies on the topic are complex and several limitations still have to be overcome in future studies. If an association between swimming and asthma in childhood exists, the direction of the association, and therefore its causality, should be clarified. On one hand, a healthy swimmer effect may occur (i.e. children with asthma abandon swimming and therefore healthier children are found among studied swimmers) but also the other may occur since swimming is a recommended sport for asthmatics. This selection bias is not directly solved in a longitudinal study and should be carefully addressed in the studies. Exposure assessment should be also improved with more data on the levels of potential irritants in swimming-pool's air and with validated questions on swimming pool attendance. Furthermore, swimming in pools entails two kinds of exposures with an impact on the respiratory health: chemical (or biological) exposure and physical activity. Finally, future studies should measure potential confounding more carefully, especially other forms of physical activity.

Baby swimming, i.e. swimming pool attendance during the first year of life, has become a popular activity in many countries. This is a vulnerable period of life, and some studies have evaluated the effect of this activity on the subsequent respiratory health of the children. Overall, no increased risk of wheezing or respiratory infections has been observed, but inconsistent results have been described among baby swimmers with atopic mothers [90, 91].

Although further studies are still needed, most of the scientific evidence does not support the hypothesis that recreational swimming increases the risk of childhood asthma. The benefits of swimming (prevention of obesity, diabetes, etc) seem to largely outweigh the potential risks of chemical contamination, as concluded by the Superior Health Council of the Belgian Government [92]. Based on the precautionary principle, this report by the Belgian Government does not encourage swimming in chlorinated pools during the first year of life especially among babies with atopic or asthmatic parents. They argue that the health benefits of baby swimming are less pronounced that swimming after being 3 or 4 and these benefits may be acquired with other activities.

\section{CANCER AND ADVERSE REPRODUCTIVE OUTCOMES}

Epidemiologic evidence indicates that exposure to THM, the most concentrated DBP, relates to 
an increased risk of bladder cancer [93, 94]. Only one study have assessed specifically this exposure through swimming pools and found increased bladder cancer risk among subjects who had attended swimming pools [95]. Nelemans, et al. [96] observed a positive association between a history of swimming and melanoma risk, suggesting that carcinogenic agents in water, possibly chlorination by products, play a role in melanoma aetiology. Evidence for an increased risk of other types of cancers have not been evaluated in relation to exposure through swimming pools. Other health risks that have been studied in relation to DBP exposure are adverse reproductive outcomes. Small DBP molecules can pass from the mother to the foetus through the placenta $[97,98]$. Evidence from animal experiments shows a range of adverse reproductive effects, including sperm toxicity, teratogenicity, and reduced fetal growth [99]. Epidemiological studies reported inconsistent results [99, 100], but recent reviews and meta-analysis indicate little or no evidence that THM exposure through different routes during pregnancy is associated to fetal growth [101] and congenital anomalies [102]. Specific studies on exposure through swimming pools overall also indicate no effect on adverse birth outcomes [103-105]. A recent study has described lower testicular hormone levels among Belgian adolescents having attended indoor chlorinated pools [106].

\section{SHORT-TERM MOLECULAR CHANGES IN HEALTHY ADULTS: THE PISCINA STUDY}

In order to provide evidence on mechanisms of action of DBP exposure, an experimental study in 50 healthy adult volunteers was conducted to evaluate a battery of biomarkers of genotoxicity and lung damage after swimming in a chlorinated pool.

\section{General study design}

An experimental study consisting of a before-after comparison was conducted in Barcelona, Spain, in 2007. Fifty non-smoking adult volunteers, after signing informed consent, swam for 40 minutes in a chlorinated pool. THM levels were determined in pool air and water, water mutagenicity, THM levels in exhaled air, micronuclei and the comet assay in peripheral blood lymphocytes and urine mutagenicity. Blood and exhaled breath condensate (EBC) were collected and lung function and FENO were measured before and after the exposure event. CC16 and SP-D were measured in serum and 8isoprostane and cytokines in EBC. Urine samples were collected before and 2 weeks after the swimming session. Chronic respiratory symptoms, usual swimming habits, water use, diet and lifestyle factors were collected through an extensive questionnaire. In addition, gas chromatography (GC)/mass spectrometry (MS) was used to comprehensively identify DBPs in pool waters. More detailed methods have been published $[5,107,108]$.

\section{Exposure}

The mean level of free chlorine in pool water (1.28 $\mathrm{mg} / \mathrm{L}$ ) was similar to that found typically in drinking water [5]. More than 100 DBPs were comprehensively identified in the pool waters and all contained either bromine or chlorine and no iodinated DBPs were detected. Most DBPs had not been reported previously for swimming pool waters [5]. Total THM levels in pool water were around $50 \mu \mathrm{g} /$ $\mathrm{L}$ and $72 \mu \mathrm{g} / \mathrm{m}^{3}$ in air [5]. After swimming, THMs in exhaled breath of swimmers increased on average about seven-fold. No differences were observed by age group, sex, or body mass index [107]. The measured THM concentrations in exhaled breath constitute about one eighth of the ambient indoor concentrations [15]. Chloroform levels in exhaled breath were significantly correlated with levels in the swimming pool air, but not with water levels. Dichloramine in water was inversely and significantly correlated with brominated THMs but not with chloroform in water, air, and exhaled breath. Free chlorine in water was not significantly correlated to total THMs in water but was significantly correlated to total THMs in air and exhaled breath. The energy expenditure of volunteers correlated significantly only with bromoform concentration in exhaled breath after swimming [107]. Trichloramine in water was undetectable and trichloramine in the air ranged from 0.17 to $0.43 \mathrm{mg} / \mathrm{m}^{3}$ (mean, $0.29 \mathrm{mg} /$ $\mathrm{m}^{3}$ ), which is below the World Health Organization recommendations of $0.5 \mathrm{mg} / \mathrm{m}^{3}$ [5].

\section{Respiratory outcomes}

Molecular markers measured included biomarkers of airway inflammation (exhaled nitric oxide -FENO- and cytokines in EBC), oxidative stress (8-isoprostane), lung permeability and immunological response (surfactant protein -SP-D) and lung damage (Clara cell protein -CC16-). We detected no significant changes in lung function (percent predicted FEV1, FVC, FEV1/FVC), airway inflammation (measured with $\mathrm{FeNO}$ and cytokines in $\mathrm{EBC}$ ) or oxidative stress (measured with 8-isoprostane in EBC). The concentration of $\mathrm{CC} 16$ in serum, which is a marker of lung epithelium permeability, was increased slightly but significantly after swimming 40 minutes, with an overall median increase of 0.47 $\mu \mathrm{g} / \mathrm{L}(3.3 \%$ increase) [107]. The increase in serum CC16 concentration was significantly correlated with different indicators of DBP exposure (negatively with dichloramine in water and positively with free chlorine in water and bromodichloromethane, dibromochloromethane, and bromoform in exhaled breath) and with energy expenditure, an indicator of physical activity. In multivariate models, both energy expenditure and markers of DBP exposure remained significantly associated with the increase in $\mathrm{CC} 16$ after mutual adjustment suggesting that these exposures may contribute to the change in lung permeability [107]. However, given the moderate increase detected, the high variability in $\mathrm{CC} 16$ 
levels in healthy subjects [109] and the lack of reference values of $\mathrm{CC16}$, the clinical relevance of this short-term effect is unclear [110] and further studies are necessary to establish the health impacts of short-term serum CC16 changes [109, 111].

\section{Genotoxicity}

The comet assay was conducted in peripheral blood lymphocytes (PBLs). One hundred cells selected randomly (50 cells from each of the two replicate slides) were analyzed per sample. Olive tail moment (OTM) and percentage of DNA in the tail, used as measures of DNA damage, were computed using Komet software, version 5.5 (Kinetic Imaging, Liverpool, UK). The micronuclei (MN) assay was conducted in PBL and urothelial cells. To determine the frequency of binucleated cells with $\mathrm{MN}$ and the total number of $\mathrm{MN}$, a total of 1000 binucleated cells with well-preserved cytoplasm (500/replicate) were scored for each subject. In addition, we scored 500 lymphocytes to evaluate the percentage of cells with one to four nuclei and calculated the cytokinesis block proliferation index. The frequency of urothelial cells with $\mathrm{MN}$ and the total number of $\mathrm{MN}$ were determined for each analyzed subject. We used generalized estimating equations (GEE) to assess associations between THM exposure and changes in genotoxicity markers before and after swimming [108]. A statistically significant increase was found for PBL MN in relation to changes in total THMs in exhaled air. This increase was more pronounced for brominated compounds and was not statistically significant for chloroform. No changes were found for the comet assay. We found no significant associations with changes in micronucleated urothelial cells. Adjustment for several potentially confounding factors did not modify results [108].

\section{OVERALL CONCLUSIONS}

The health effects that have been evaluated in relation to DBP exposure in swimming pools include adverse reproductive outcomes, carcinogenicity and respiratory outcomes. Epidemiological evidence does not support an increased risk of reproductive outcomes after swimming in pools during pregnancy. However, a study suggested an increased risk of bladder cancer with swimming pool attendance, although results are far from being conclusive. Extensive research has been conducted to evaluate respiratory outcomes associated with swimming pool attendance. Evidence indicates that the association between asthma risk and swimming depends on the target population [54]. A higher prevalence of respiratory symptoms including asthma is found among those occupationally exposed to the pool environment, although the causality of this association is uncertain. Studies in children are less conclusive but the only longitudinal and prospective study indicates that asthma is not increased by swimming pool attendance [84]. Overall, the available evidence supports that the health benefits of swimming during childhood and adulthood outweigh the potential health risks of chemical contamination [92]. However, the positive effects of swimming should be increased by minimising potential risks. Given the high public health relevance of the topic and the existing uncertainties, further research is needed to draw final conclusions about the risk of respiratory problems during childhood for swimming in well maintained swimming pools. The maximum level proposed for trichloramine in air as provisional guideline [1] should be revised [112, 113] and regulated. Also, the potential carcinogenicity of this environment should be further explored. Efforts should be done to identify which specific DBPs are responsible for the toxicity, to be monitored DBPs in swimming pools [92].

\section{Conflict of interest statement}

There are no potential conflicts of interest or any financial or personal relationships with other people or organizations that could inappropriately bias conduct and findings of this study.

Submitted on invitation.

Accepted on 24 September 2012.

\section{References}

1. World Health Organization. Guidelines for safe recreational water environments. Volume 2. Swimming pools and similar environments. Geneva: WHO; 2006.

2. Zwiener C, Richardson SD, De Marini DM, Grummt T, Glauner T, Frimmel FH. Drowning in disinfection byproducts? Assessing swimming pool water. Environ Sci Technol 2007:41(2):363-72. http://dx.doi.org/10.1021/es062367v

3. Kim H, Shim J, Lee S. Formation of disinfection by-products in chlorinated swimming pool water. Chemosphere 2002;46(1):123-30. http://dx.doi.org/10.1016/S0045-6535(00)00581-6

4. Richardson SD, Plewa MJ, Wagner ED, Schoeny R, DeMarini DM. Occurrence, genotoxicity, and carcinogenicity of regulated and emerging disinfection by-prod-

ucts in drinking water. A review and roadmap for research. Mutat Res 2007;636(1-3):178-242.

http://dx.doi.org/10.1016/j.mrrev.2007.09.001

5. Richardson SD, DeMarini DM, Kogevinas M, Fernandez P, Marco E, Lourencetti C, et al. What's in the pool? A comprehensive identification of disinfection by-products and assessment of mutagenicity of chlorinated and brominated swimming pool water. Environ Health Perspect 2010;118(11):1523-30.

http://dx.doi.org/10.1289/ehp.1001965

6. Serrano M, Silva M, Gallego M. Micro liquid-liquid extraction combined with large-volume injection gas chromatography-mass spectrometry for the determination of haloacetaldehydes in treated water. J Chromatogr A 2011; 1218(46):8295-302.

http://dx.doi.org/10.1016/j.chroma.2011.09.048 
7. Weaver WA, Li J, Wen Y, Johnston J, Blatchley MR, Blatchley ER, III. Volatile disinfection by-product analysis from chlorinated indoor swimming pools. Water Res 2009; 43(13):3308-18. http://dx.doi.org/10.1016/j.watres.2009.04.035

8. Walse SS, Mitch WA. Nitrosamine carcinogens also swim in chlorinated pools. Environ Sci Technol 2008;42(4):1032-7. http://dx.doi.org/10.1021/es702301p

9. Jurado-Sanchez B, Ballesteros E, Gallego M. Screening of $\mathrm{N}$-nitrosamines in tap and swimming pool waters using fast gas chromatography. J Sep Sci 2010;33(4-5):610-6. http://dx.doi.org/10.1002/jssc.200900679

10. Schmalz C, Frimmel FH, Zwiener C. Trichloramine in swimming pools-formation and mass transfer. Water Res 2011;45(8):2681-90 http://dx.doi.org/10.1016/j.watres.2011.02.024

11. Lee J, Jun MJ, Lee MH, Lee MH, Eom SW, Zoh KD. Production of various disinfection byproducts in indoor swimming pool waters treated with different disinfection methods. Int J Hyg Environ Health 2010;213(6):465-74. http://dx.doi.org/10.1016/j.ijheh.2010.09.005

12. Sa CS, Boaventura RA, Pereira IB. Analysis of haloacetic acids in water and air (aerosols) from indoor swimming pools using HS-SPME/GC/ECD. J Environ Sci Health A Tox Hazard Subst Environ Eng 2012;47(2):176-83. http://dx.doi.org/10.1080/10934529.2012.640246

13. Chu H, Nieuwenhuijsen MJ. Distribution and determinants of trihalomethane concentrations in indoor swimming pools. Occup Environ Med 2002;59(4):243-47. http://dx.doi.org/10.1136/oem.59.4.243

14. Santa Marina L, Ibarluzea J, Basterrechea M, Goni F, Ulibarrena E, Artieda J, et al. Indoor air and bathing water pollution in indoor swimming pools in Guipuzcoa (Spain). Gac Sanit 2009;23(2):115-20.

15. Lourencetti C, Grimalt JO, Marco E, Fernandez P, FontRibera L, Villanueva CM, Kogevinas M. Trihalomethanes in chlorine and bromine disinfected swimming pools: Airwater distributions and human exposure. Environ Int 2012; 45:59-67.

http://dx.doi.org/10.1016/j.envint.2012.03.009

16. Bessonneau V, Derbez M, Clement M, Thomas O. Determinants of chlorination by-products in indoor swimming pools. Int J Hyg Environ Health 2011;215(1):76-85. http://dx.doi.org/10.1016/j.ijheh.2011.07.009

17. Aggazzotti G, Fantuzzi G, Righi E, Predieri G. Environmental and biological monitoring of chloroform in indoor swimming pools. J Chromatogr A 1995;710(1):181-90. http://dx.doi.org/10.1016/0021-9673(95)00432-M

18. Font-Ribera L, Esplugues A, Ballester F, Martinez B, Tardon A, Freire C, et al. Trihalomethanes in swimming pool water in four areas in Spain 1 participating in the INMA project. Gac Sanit 2010a;24(6):483-6.

19. Weng SC, Weaver WA, Zare AM, Blatchley TN, Cramer JS, Chen J, et al. Dynamics of gas-phase trichloramine $\left(\mathrm{NCl}_{3}\right)$ in chlorinated, indoor swimming pool facilities. Indoor Air 2011;21(5)391-9.

http://dx.doi.org/10.1111/j.1600-0668.2011.00710.x

20. Liviac D, Wagner ED, Mitch WA, Altonji MJ, Plewa MJ. Genotoxicity of water concentrates from recreational pools after various disinfection methods. Environ Sci Technol 2010; 44(9):3527-32.

http://dx.doi.org/10.1021/es903593w

21. Glauner T, Waldmann P, Frimmel FH, Zwiener C. Swimming pool water-fractionation and genotoxicological characterization of organic constituents. Water Res 2005;39(18):4494-502. http://dx.doi.org/10.1016/j.watres.2005.09.005
22. Klupfel AM, Glauner T, Zwiener C, Frimmel FH. Nanofiltration for enhanced removal of disinfection by-product (DBP) precursors in swimming pool water-retention and water quality estimation. Water Sci Technol 2011; 63(8):1716-25. http://dx.doi.org/10.2166/wst.2011.213

23. Weng S, Li J, Blatchley ER, III. Effects of UV (254) irradiation on residual chlorine and DBPs in chlorination of model organic-N precursors in swimming pools. Water Res 2012;46(8):2674-82 http://dx.doi.org/10.1016/j.watres.2012.02.017

24. Hua G, Reckhow DA. Comparison of disinfection byproduct formation from chlorine and alternative disinfectants. Water Res 2007;41(8):1667-78.

http://dx.doi.org/10.1016/j.watres.2007.01.032

25. Huang WJ, Chang CY, Shih FH. Disinfection by-product formation and mutagenic assay caused by preozonation of groundwater containing bromide. Environ Monit Assess 2009; 158(1-4):181-96. http://dx.doi.org/10.1007/s10661-008-0572-3

26. European Union. The Drinking Water Directive. Council Directive 98/83/EC of 3 November 1998 on the quality of water intended for human consumption. Official Journal L 330, 05/12/1998. p. 32-54.

27. US Environmental Protection Agency. Current EPA microbial and disinfection byproduct regulations. Atlanta: US EPA; 1998. Available from: www.epa.gov/enviro/html/icr/regulations.html.

28. Li J, Blatchley ER, III. Volatile disinfection byproduct formation resulting from chlorination of organic-nitrogen precursors in swimming pools. Environ Sci Technol 2007;41(19):6732-9. http://dx.doi.org/10.1021/es070871+

29. Font-Ribera L, Kogevinas M, Nieuwenhuijsen MJ, Grimalt JO, Villanueva CM. Patterns of water use and exposure to trihalomethanes among children in Spain. Environ Res 2010b; 110(6):571-9.

http://dx.doi.org/10.1016/j.envres.2010.05.008

30. Aggazzotti G, Fantuzzi G, Righi E, Predieri G. Blood and breath analyses as biological indicators of exposure to trihalomethanes in indoor swimming pools. Sci Total Environ 1998;217(1-2):155-63. http://dx.doi.org/10.1016/S0048-9697(98)00174-0

31. Cammann K, Hubner K. Trihalomethane concentrations in swimmers' and bath attendants' blood and urine after swimming or working in indoor swimming pools. Arch Environ Health 1995;50(1):61-5. http://dx.doi.org/10.1080/00039896.1995.9955013

32. Caro J, Gallego M. Assessment of exposure of workers and swimmers to trihalomethanes in an indoor swimming pool. Environ Sci Technol 2007;41(13):4793-8. http://dx.doi.org/10.1021/es070084c

33. Caro J, Gallego M. Alveolar air and urine analyses as biomarkers of exposure to trihalomethanes in an indoor swimming pool. Environ Sci Technol 2008;42(13):5002-7. http://dx.doi.org/10.1021/es800415p

34. Fantuzzi G, Righi E, Predieri G, Ceppelli G, Gobba F, Aggazzotti G. Occupational exposure to trihalomethanes in indoor swimming pools. Sci Total Environ 2001;264(3):257-65. http://dx.doi.org/10.1016/S0048-9697(00)00722-1

35. Aggazzotti G, Fantuzzi G, Righi E, Tartoni P, Cassinadri T, Predieri G. Chloroform in alveolar air of individuals attending indoor swimming pools. Arch Environ Health 1993; 48(4):250-4. http://dx.doi.org/10.1080/00039896.1993.9940368

36. Aggazzotti G, Fantuzzi G, Tartoni PL, Predieri G. Plasma chloroform concentrations in swimmers using indoor swimming pools. Arch Environ Health 1990;45(3):175-9. http://dx.doi.org/10.1080/00039896.1990.9936712 
37. Levesque B, Ayotte P, LeBlanc A, Dewailly E, Prud'Homme $\mathrm{D}$, Lavoie R, et al. Evaluation of dermal and respiratory chloroform exposure in humans. Environ Health Perspect 1994;102(12):1082-7. http://dx.doi.org/10.2307/3431996

38. Erdinger L, Kuhn KP, Kirsch F, Feldhues R, Frobel T, Nohynek B, et al. Pathways of trihalomethane uptake in swimming pools. Int J Hyg Environ Health 2004;207(6):5715. http://dx.doi.org/10.1078/1438-4639-00329

39. Lindstrom AB, Pleil JD, Berkoff DC. Alveolar breath sampling and analysis to assess trihalomethane exposures during competitive swimming training. Environ Health Perspect 1997;105(6):636-42.

http://dx.doi.org/10.1289/ehp.97105636

40. Cardador MJ, Gallego M. Haloacetic acids in swimming pools: swimmer and worker exposure. Environ Sci Technol 2011;45(13):5783-90. http://dx.doi.org/10.1021/es103959d

41. Martinez TT, Long C. Explosion risk from swimming pool chlorinators and review of chlorine toxicity. $J$ Toxicol Clin Toxicol 1995;33:349-54. http://dx.doi.org/10.3109/15563659509028921

42. Agabiti N, Ancona C, Forastiere F, Di Napoli A, Lo PE, Corbo GM, et al. Short term respiratory effects of acute exposure to chlorine due to a swimming pool accident. Occup Environ Med 2001;58:399-404 http://dx.doi.org/10.1136/oem.58.6.399

43. Parimon T, Kanne JP, Pierson DJ. Acute inhalation injury with evidence of diffuse bronchiolitis following chlorine gas exposure at a swimming pool. Respir Care 2004;49:291-4.

44. Bonetto G, Corradi M, Carraro S, Zanconato S, Alinovi R, Folesani, et al. Longitudinal monitoring of lung injury in children after acute chlorine exposure in a swimming pool. Am J Respir Crit Care Med 2006;174:545-9. http://dx.doi.org/10.1164/rccm.200509-1392OC

45. Babu RV, Cardenas V, Sharma G. Acute respiratory distress syndrome from chlorine inhalation during a swimming pool accident: a case report and review of the literature. $J$ Intensive Care Med 2008:23:275-80. http://dx.doi.org/10.1177/0885066608318471

46. Bougault V, Turmel J, Levesque B, \& Boulet LP. The respiratory health of swimmers. Sports Med 2009;39:295-312. http://dx.doi.org/10.2165/00007256-200939040-00003

47. Massin N, Bohadana AB, Wild P, Héry M, Toamain JP, Hubert G. Respiratory symptoms and bronchial responsiveness in lifeguards exposed to nitrogen trichloride in indoor swimming pools. Occup Environ Med 1998;55(4):258-63. http://dx.doi.org/10.1136/oem.55.4.258

48. Jacobs JH, Spaan S, van Rooy GB, Meliefste C, Zaat VA, Rooyackers JM, Heederik D. Exposure to trichloramine and respiratory symptoms in indoor swimming pool workers. Eur Respir J 2007;29(4):690-8. http://dx.doi.org/10.1183/09031936.00024706

49. Fantuzzi G, Righi E, Predieri G, Giacobazzi P, Mastroianni K, Aggazzotti G. Prevalence of ocular, respiratory and cutaneous symptoms in indoor swimming pool workers and exposure to disinfection by-products (DBPs). Int $J$ Environ Res Public Health 2010;7(4):1379-91. http://dx.doi.org/10.3390/ijerph7041379

50. Centers for Disease Control and Prevention (CDC). Respiratory and ocular symptoms among employees of a hotel indoor waterpark resort, Ohio, 2007. MMWR Morb Mortal Wkly Rep 2009;58(4):81-5.

51. Thickett KM, McCoach JS, Gerber JM, Sadhra S, Burge PS. Occupational asthma caused by chloramines in indoor swimming-pool air. Eur Respir J 2002;19(5):827-32. http://dx.doi.org/10.1183/09031936.02.00232802
52. Levesque B, Duchesne JF, Gingras S, Lavoie R, Prud'Homme $\mathrm{D}$, Bernard $\mathrm{E}$, et al. The determinants of prevalence of health complaints among young competitive swimmers. Int Arch Occup Environ Health 2006;80:32-9. http://dx.doi.org/10.1007/s00420-006-0100-0

53. Fisk MZ, Steigerwald MD, Smoliga JM, Rundell KW Asthma in swimmers: A review of the current literature. Phys Sportsmed 2010;38(4):28-34. http://dx.doi.org/10.3810/psm.2010.12.1822

54. Goodman M, \& Hays S. Asthma and swimming: a metaanalysis. J Asthma 2008;45:639-47. http://dx.doi.org/10.1080/02770900802165980

55. Uyan ZS, Carraro S, Piacentini G, Baraldi E. Swimming pool, respiratory health, and childhood asthma: should we change our beliefs? Pediatr Pulmonol 2009;44:31-7. http://dx.doi.org/10.1002/ppul.20947

56. Weisgerber M, Webber K, Meurer J, Danduran M, Berger S, Flores G. Moderate and vigorous exercise programs in children with asthma: safety, parental satisfaction, and asthma outcomes. Pediatr Pulmonol 2008;43:1175-82. http://dx.doi.org/10.1002/ppul.20895

57. Wheezing at the swimming pool. Lancet 1979;2:1342-3.

58. American Academy of Pediatrics. Section on allergy and immunology; section on diseases of the chest. Exercise and the asthmatic child. Pediatrics 1989;84:392-3.

59. Päivinen MK, Keskinen KL, Tikkanen HO. Swimming and asthma: factors underlying respiratory symptoms in competitive swimmers. Clin Respir J 2010;4(2):97-103. http://dx.doi.org/10.1111/j.1752-699X.2009.00155.x

60. Romberg K, Tufvesson E, Bjermer L. Asthma is more prevalent in elite swimming adolescents despite better mental and physical health. Scand J Med Sci Sports 2012;22(3):362-71. http://dx.doi.org/10.1111/j.1600-0838.2010.01177.x

61. Reich JD. Criticism of infant swimming practice is political, not scientific. Pediatrics 2007;120(4):926-7. http://dx.doi.org/10.1542/peds.2007-1672

62. Spivey A. Widening the pool of factors: studies needed to assess asthma swimming link. Environ Health Perspect 2009;117:A162.

63. Weisel CP, Richardson SD, Nemery B, Aggazzotti G, Baraldi E, Blatchley ER III, Blount BC, Carlsen KH, Eggleston PA, Frimmel FH, et al. Childhood asthma and environmental exposures at swimming pools: state of the science and research recommendations. Environ Health Perspect 2009;117:500-7. http://dx.doi.org/10.1289/ehp.11513

64. Bernard A, Voisin C, Sardella A. Con: respiratory risks associated with chlorinated swimming pools: a complex pattern of exposure and effects. Am J Respir Crit Care Med; 2011;183(5):570-2. http://dx.doi.org/10.1164/rccm.201008-1306ED

65. Piacentini GL, Baraldi E. Pro: swimming in chlorinated pools and risk of asthma: we can now carry on sending our children to swimming pools! Am J Respir Crit Care Med 2011;183(5):569-70. http://dx.doi.org/10.1164/rccm.201008-1277ED

66. Downing L. Swimming pools and asthma: a new risk or premature concern? Contemp Nurse 2011;37(2):225-6.

67. Sabourin G. Asthma and chlorine. Do indoor chlorinated pools lead to childhood asthma? Perspect Infirm 2011;8(5):43.

68. Klootwijk T, Krul M. Some concerns remain about the proposed association between swimming and asthma. Am J Respir Crit Care Med 2011;184(12):1419.

69. Florentin A, Hautemanière A, Hartemann P. Health effects of disinfection by-products in chlorinated swimming pools. Int J Hyg Environ Health 2011;214(6):461-9. http://dx.doi.org/10.1016/j.ijheh.2011.07.012 
70. O'Connell EJ. The burden of atopy and asthma in children. Allergy 2004;59:7-11. http://dx.doi.org/10.1111/j.1398-9995.2004.00563.x

71. Selgrade MK, Lemanske RF, Gilmour MI, Neas LM, Ward MD, Henneberger PK, et al. Induction of asthma and the environment: what we know and need to know. Environ Health Perspect 2006;114:615-9. http://dx.doi.org/10.1289/ehp.8376

72. Vaz de Almeida MD, Gracxa P, Afonso C, D'Amicis A, Lappalainen R, Damkjaer S. Physical activity levels and body weight in a nationally representative sample in the European Union. Public Health Nutr 1999;2:105-13. http://dx.doi.org/10.1017/S1368980099000154

73. Hardy LR, Harrell JS, Bell RA. Overweight in children: definitions, measurements, confounding factors, and health consequences. J Pediatr Nurs 2004;19:376-84.

http://dx.doi.org/10.1016/j.pedn.2004.11.001

74. Bernard A, Carbonnelle S, de Burbure C, Michel O, Nickmilder M. Chlorinated pool attendance, atopy, and the risk of asthma during childhood. Environ Health Perspect 2006;114:1567-73.

http://dx.doi.org/10.1289/ehp.8461

75. Bernard A, Carbonnelle S, Dumont X, Nickmilder M. Infant swimming practice, pulmonary epithelium integrity, and the risk of allergic and respiratory diseases later in childhood. Pediatrics 2007;119:1095-103.

http://dx.doi.org/10.1542/peds.2006-3333

76. Bernard A, Nickmilder M, Voisin C. Outdoor swimming pools and the risks of asthma and allergies during adolescence. Eur Respir J 2008;32:979-88. http://dx.doi.org/10.1183/09031936.00114807

77. Kohlhammer Y, Doring A, Schafer T, Wichmann HE, Heinrich J. Swimming pool attendance and hay fever rates later in life. Allergy 2006;61:1305-9. http://dx.doi.org/10.1111/j.1398-9995.2006.01229.x

78. Schoefer Y, Zutavern A, Brockow I, Schafer T, Kramer U, Schaaf B, Herbarth O, von Berg A, Wichmann HE, Heinrich J. Health risks of early swimming pool attendance. Int J Hyg Environ Health 2008;211:367-73.

http://dx.doi.org/10.1016/j.ijheh.2007.08.001

79. Carraro S, Pasquale MF, Da Fre M, Rusconi F, Bonetto G, Zanconato S, Baraldi E. Swimming pool attendance and exhaled nitric oxide in children. J Allergy Clin Immunol 2006; 118:958-60. http://dx.doi.org/10.1016/j.jaci.2006.07.016

80. Bernard A, Nickmilder M, Voisin C, Sardella A. Impact of chlorinated swimming pool attendance on the respiratory health of adolescents. Pediatrics 2009;124:1110-8. http://dx.doi.org/10.1542/peds.2009-0032

81. Voisin C, Sardella A, Marcucci F, Bernard A. Infant swimming in chlorinated pools and the risks of bronchiolitis, asthma and allergy. Eur Respir J 2010;36(1):41-7. http://dx.doi.org/10.1183/09031936.00118009

82. Cotter A, Ryan CA. The pool chlorine hypothesis and asthma among boys. Ir Med $J$ 2009;102:79-82.

83. Font-Ribera L, Kogevinas M, Zock JP, Nieuwenhuijsen MJ, Heederik D, Villanueva CM. Swimming pool attendance and risk of asthma and allergic symptoms in children. Eur Respir J 2009;34:1304-10. http://dx.doi.org/10.1183/09031936.00180608

84. Font-Ribera L, Villanueva CM, Nieuwenhuijsen MJ, Zock JP, Kogevinas M, Henderson J. Swimming pool attendance, asthma, allergies, and lung function in the Avon Longitudinal Study of Parents and Children cohort. Am J Respir Crit Care Med 2011;183(5):582-8 http://dx.doi.org/10.1164/rccm.201005-0761OC
85. Rasmussen F, Lambrechtsen J, Siersted HC, Hansen HS, Hansen NC. Low physical fitness in childhood is associated with the development of asthma in young adulthood: the Odense schoolchild study. Eur Respir J 2000;16:866-70. http://dx.doi.org/10.1183/09031936.00.16586600

86. Sherriff A, Maitra A, Ness AR, Mattocks C, Riddoch C, Reilly JJ, Paton JY, Henderson AJ. Association of duration of television viewing in early childhood with the subsequent development of asthma. Thorax 2009;64(4):321-5. http://dx.doi.org/10.1136/thx.2008.104406

87. Shaaban R, Leynaert B, Soussan D, Antó JM, Chinn S, de Marco R, Garcia-Aymerich J, Heinrich J, Janson C, Jarvis D, Sunyer J, Svanes C, Wjst M, Burney PG, Neukirch F, Zureik M. Physical activity and bronchial hyperresponsiveness: European Community Respiratory Health Survey II. Thorax 2007;62(5):403-10. http://dx.doi.org/10.1136/thx.2006.068205

88. Wang JS, Hung WP. The effects of a swimming intervention for children with asthma. Respirology 2009;14:838-42. http://dx.doi.org/10.1111/j.1440-1843.2009.01567.x

89. Macrì F, Valerio M, Elena $\mathrm{B}$, Emanuela $\mathrm{C}$, Caterina L. Relationship between chlorinated pools and bronchial asthma. Pediatr Pulmonol 2011;46(1):96-7. http://dx.doi.org/10.1002/ppul.21344

90. Nystad W, Nja F, Magnus P, Nafstad P. Baby swimming increases the risk of recurrent respiratory tract infections and otitis media. Acta Paediatr 2003;92:905-9. http://dx.doi.org/10.1111/j.1651-2227.2003.tb00622.x

91. Nystad W, Haberg SE, London SJ, Nafstad P, Magnus P. Baby swimming and respiratory health. Acta Paediatr 2008; 97:657-62. http://dx.doi.org/10.1111/j.1651-2227.2008.00756.x

92. Belgium. Superior Health Council. The issue of chlorine in swimming pools: risk attendant on baby swimming and reflections on the different methods used to disinfect swimming pools. Brussels: SHC; 2012.

93. Costet N, Villanueva CM, Jaakkola JJ, Kogevinas M, Cantor KP, King WD, Lynch CF, Nieuwenhuijsen MJ, Cordier S. Water disinfection by-products and bladder cancer: is there a European specificity? A pooled and metaanalysis of European case-control studies. Occup Environ Med 2011;68(5):379-85. http://dx.doi.org/10.1136/oem.2010.062703

94. Villanueva CM, Cantor KP, Cordier S, Jaakkola JJ, King WD, Lynch CF, Porru S, Kogevinas M. Disinfection byproducts and bladder cancer: a pooled analysis. Epidemiology 2004;15(3):357-67. http://dx.doi.org/10.1097/01.ede.0000121380.02594.fc

95. Villanueva CM, Cantor KP, Grimalt JO, Malats N, Silverman D, Tardon A, et al. Bladder cancer and exposure to water disinfection by-products through ingestion, bathing, showering and swimming pool attendance. Am $J$ Epidemiol 2007;165(2):148-56. http://dx.doi.org/10.1093/aje/kwj364

96. Nelemans PJ, Rampen FH, Groenendal H, Kiemeney LA, Ruiter DJ, Verbeek AL. Swimming and the risk of cutaneous melanoma. Melanoma Res 1994;4(5):281-6. http://dx.doi.org/10.1097/00008390-199410000-00002

97. Danielsson BR, Ghantous H, Dencker L. Distribution of chloroform and methyl chloroform and their metabolites in pregnant mice. Biol Res Pregnancy Perinatol 1986;7:77-83.

98. Dowty BJ, Laseter JL, Storer J. The transplacental migration and accumulation in blood of volatile organic constituents. Pediatr Res 1976;10:696-701. http://dx.doi.org/10.1203/00006450-197610070-00013

99. Tardiff RG, Carson ML, Ginevan ME. Updated weight of evidence for an association between adverse reproductive 
and developmental effects and exposure to disinfection byproducts. Regul Toxicol Pharmacol 2006;45(2):185-205. http://dx.doi.org/10.1016/j.yrtph.2006.03.001

100. Villanueva CM, Gracia-Lavedán E, Ibarluzea J, Santa Marina L, Ballester F, Llop S, Tardón A, Fernández MF, Freire C, Goñi F, Basagaña X, Kogevinas M, Grimalt JO, Sunyer J; INMA (Infancia y Medio Ambiente) Project. Exposure to trihalomethanes through different water uses and birth weight, small for gestational age, and preterm delivery in Spain. Environ Health Perspect 2011;119(12):1824-30. http://dx.doi.org/10.1289/ehp.1002425

101. Grellier J, Bennett J, Patelarou E, Smith RB, Toledano MB, Rushton L, Briggs DJ, Nieuwenhuijsen MJ. Exposure to disinfection by-products, fetal growth, and prematurity: a systematic review and meta-analysis. Epidemiology 2010;21(3):300-13. http://dx.doi.org/10.1097/EDE.0b013e3181d61ffd

102. Nieuwenhuijsen MJ, Martinez D, Grellier J, Bennett J, Best $\mathrm{N}$, Iszatt N, Vrijheid M, Toledano MB. Chlorination disinfection by-products in drinking water and congenital anomalies: review and meta-analyses. Environ Health Perspect 2009b; 117(10):1486-93. http://dx.doi.org/10.1289/ehp.0900677

103. Nieuwenhuijsen MJ, Northstone K, Golding J. ALSPAC Study Team. Swimming and birth weight. Epidemiology 2002; 13(6):725-8. http://dx.doi.org/10.1097/00001648-200211000-00020

104. Juhl M, Kogevinas M, Andersen PK, Andersen AM, Olsen J. Is swimming during pregnancy a safe exercise? Epidemiology 2010;21(2):253-8 http://dx.doi.org/10.1097/EDE.0b013e3181cb6267

105. Patelarou E, Kargaki S, Stephanou EG, Nieuwenhuijsen M, Sourtzi P, Gracia E, Chatzi L, Koutis A, Kogevinas M. Exposure to brominated trihalomethanes in drinking water and reproductive outcomes. Occup Environ Med 2011; 68(6):438-45.

http://dx.doi.org/10.1136/oem.2010.056150
106. Nickmilder M, Bernard A. Associations between testicular hormones at adolescence and attendance at chlorinated swimming pools during childhood. Int J Androl 2011;34(5 Pt 2). http://dx.doi.org/10.1111/j.1365-2605.2011.01174.x

107. Font-Ribera L, Kogevinas M, Zock JP, Gomez FP, Barreiro E, Nieuwenhuijsen MJ, et al. Short-term changes in respiratory biomarkers after swimming in a chlorinated pool. Environ Health Perspect 2010c;118(11):1538-44. http://dx.doi.org/10.1289/ehp.1001961

108. Kogevinas M, Villanueva CM, Font-Ribera L, Liviac D, Bustamante M, Espinoza F, et al. Genotoxic effects in swimmers exposed to disinfection by-products in indoor swimming pools. Environ Health Perspect 2010;118(11):1531-7. http://dx.doi.org/10.1289/ehp.1001959

109. Broeckaert F, Clippe A, Knoops B, Hermans C, Bernard A. Clara cell secretory protein (CC16): features as a peripheral lung biomarker. Ann N Y Acad Sci 2000;923:68-77. http://dx.doi.org/10.1111/j.1749-6632.2000.tb05520.x

110. Carbonnelle S, Bernard A, Doyle IR, Grutters J, Francaux M. Fractional exhaled NO and serum pneumoproteins after swimming in a chlorinated pool. Med Sci Sports Exerc 2008;40(8):1472-6. http://dx.doi.org/10.1249/MSS.0b013e3181733159

111. Lakind JS, Holgate ST, Ownby DR, Mansur AH, Helms PJ, Pyatt D, Hays SM. A critical review of the use of Clara cell secretory protein $(\mathrm{CC16})$ as a biomarker of acute or chronic pulmonary effects. Biomarkers 2007;12(5):445-67. http://dx.doi.org/10.1080/13547500701359327

112. Parrat J, Donzé G, Iseli C, Perret D, Tomicic C, Schenk O. Assessment of occupational and public exposure to trichloramine in Swiss indoor swimming pools: a proposal for an occupational exposure limit. Ann Occup Hyg 2012;56(3):264-77. http://dx.doi.org/10.1093/annhyg/mer125

113. Bonvallot N, Glorennec P, Zmirou D. Derivation of a toxicity reference value for nitrogen trichloride as a disinfection by-product. Regul Toxicol Pharmacol 2010;56(3):357-64. http://dx.doi.org/10.1016/j.yrtph.2009.10.008 